\title{
O014. The diagnostic mistake: when the patient reports pain affecting eyes and benzodiazepines abuse without any glaucoma or any apparent organic cause
}

\author{
Maria Nicolodi, Olivier D'Angri \\ From Abstracts from the 1st Joint ANIRCEF-SISC Congress \\ Rome, Italy. 29-31 October 2015
}

\section{Background}

It is not so infrequent that a patient reports severe pain with a clear focus in/around the eye that looks like an atypical facial pain/persistent idiopathic facial pain. All the patients fulfilled DMS-IV criteria for depression or bipolar disorder-I and sleep and benzodiazepines overuse were reported as the only escape and cure treatment. This may or may not appear as a psychological flight reaction characterized by vegetative signs [1], or a medication-overuse headache. The diagnosis could be wrong even though the IHS/IASP and psychological criteria were respected. What could be the problem? We did not take into account that demodex is present even in man. Demodex -type A and type B-, the most serious non-neoplastic dermatological disease [2,3], is not so widely known in human pathology [4]. This ascaris provokes discomfort and pain, the severity of which depends on the extent and seriousness of the disease [2-4], as well as on the pain proneness evidenced in third hyperalgesia test we proved several years ago [5]. Thus, pain proneness and pain redundancy might be present in both migraine sufferers and in their relatives.

\section{Aim}

To evidence possible causes of therapeutic mistakes in persistent facial pain, chiefly affecting the eye area.

\section{Materials and methods}

Observation started 26 years ago. Recruited patients (53 males; mean age 33.9 years $\pm 7.5 \mathrm{SD}$ ) suffering from atypical facial pain chiefly affecting the area of the eyes, were previously treated with all the substances commonly used in such a pain, namely tricyclics, negative modulators of excitatory aminoacids, selective serotonin reuptake inhibitors and norepinephrine reuptake inhibitors given as 3-month treatments and narcotics given as hospital short-lasting (5 days) regimen. Neither indomethacin $50 \mathrm{mg}$ nor sumatriptan $6 \mathrm{mg}$, parenterally administered, induced relief.

\section{Results}

None of the patients, except one, achieved pain relief, i. e. decrease vs baseline $17 \%$ on VAS $0-10$. Only narcotics induced a benefit, which vanished when treatment was discontinued. Magnifiers observation focusing cilia showed that all non-responder patients were affected by demodex as evidenced with the use of a magnifying glass. The specific treatment for curing demodex completely relieved non-responders' pain. Later (i.e., 3-25 years; mean 19.3 years $+10.9 \mathrm{SD}$ ), episodic migraine without aura appeared in 25 patients.

\section{Conclusions}

a) When a disease is rare it does not mean it can be neglected; b) an inherited abnormality of the central nervous system, namely inheritable hyperalgesia pattern seemingly provokes a redundancy of painful expression that may lead to diagnostic mistakes.

Written informed consent to publish was obtained from the patient(s).

\footnotetext{
* Correspondence: sicuteri@iol.it

Foundation Prevention and Therapy of Primary Pain and Headache, Florence, Italy
} 


\section{References}

1. Gleitman H, Alan J, Fridlund AJ, Reisberg D: Psychology. 6 edition. New York: Norton WW. \& Company; 2004

2. Kwochka KW: Demodicosis. In Current Veterinary Therapy. St Louis USA: Mosby Year Book;Griffin CE, Kwochka KW, MacDonald JM 1983:72-84.

3. Nuttall T, Harvey RG, McKeever PJ: Skin diseases of the dog and cat London: Manson Publishing; 2009.

4. Karaman Ü, Kolören Z, Enginyurt Ö, Özer A: The epidemiology of demodex mites at the college students living in dormitories in the city of Ordu. Turkiye Parazitol Derg 2014, 38(3):166-171.

5. Nicolodi M, Sicuteri R, Coppola G, Greco E, Pietrini U, Sicuteri F: Visceral pain threshold is deeply lowered far from the head in migraine. Headache 1994, 34(1):12-19.

doi:10.1186/1129-2377-16-S1-A168

Cite this article as: Nicolodi and D'Angri: O014. The diagnostic mistake: when the patient reports pain affecting eyes and benzodiazepines abuse without any glaucoma or any apparent organic cause. The Journal of Headache and Pain 2015 16(Suppl 1):A168.

\section{Submit your manuscript to a SpringerOpen ${ }^{\odot}$ journal and benefit from:}

- Convenient online submission

- Rigorous peer review

- Immediate publication on acceptance

- Open access: articles freely available online

- High visibility within the field

- Retaining the copyright to your article

Submit your next manuscript at $>$ springeropen.com 